A RCHIWA, BIBLIOTEKI

I MUZEA KOŚCIELNE 110 (2018)

https://doi.org/10.31743/abmk.2018.110.03

MICHAŁ BARTOSZAK* - POZNAŃ

\title{
SUPEREKSLIBRISY PRYMASÓW POLSKI Z XVI I XVII WIEKU ZNAJDUJĄCE SIĘ W ARCHIWUM ARCHIDIECEZJALNYM W GNIEŹNIE
}

Wydana niedawno monograficzna praca Arkadiusza Wagnera ${ }^{1}$ prezentująca całokształt aktualnej wiedzy dotyczącej książkowych znaków własnościowych w postaci superekslibrisów, stanowiąca podstawę niewątpliwie cenną $\mathrm{w}$ badaniach księgoznawczych, z racji obfitych zasobów biblioteczno-archiwalnych, nie obejmuje jednak pełnego wykazu superekslibrisowych form znaków własnościowych stosowanych przez polskich bibliofilów. Poczynione m.in. przez Marię Cubrzyńską-Leonarczyk ${ }^{2}$, Tomasza Moskala ${ }^{3}$, Piotra Pokorę i Michała Muraszkę ${ }^{4}, \mathrm{Kazi}^{-}$ mierza Rulkę, , Stanisława Rybandta ${ }^{6}$, Marię Sipayłło ${ }^{7}$, Zbigniewa Skiełczyńskie-

* Michał Bartoszak - mgr historii; współpracownik Instytutu Historii Uniwersytetu Adama Mickiewicza w Poznaniu; e-mail: michal.bartoszak@gmail.com

ORCID 0000-0003-3483-8306

${ }^{1}$ A. Wagner, Superekslibris polski: studium o kulturze bibliofilskiej i sztuce od średniowiecza do połowy XVII wieku, Torun 2016.

${ }^{2}$ M. Cubrzyńska-Leonarczyk, Polskie superekslibrisy XVI-XVII wieku: centuria druga, Warszawa 2001, wg indeksu: Jan Latalski, Jan Tarnowski, Wojciech Baranowski, Jan Wężyk, Maciej Łubieński, Michał Stefan Augustyn Radziejowski, Teodor Andrzej Potocki.

${ }^{3}$ T. Moskal, Książki z superekslibrisami biskupów polskich okresu przedrozbiorowego w Bibliotece Diecezjalnej w Sandomierzu, w: Artem historicam aliis tradere. Księga pamiatkowa ku czci Księdza Profesora Anzelma Weissa, Lublin 2011, s. 196-199, 204.

${ }^{4}$ P. Pokora, M. Muraszko, Skarby drukarstwa i introligatorstwa ze zbiorów dawnej Biblioteki Katedralnej w Gnieźnie. Katalog wystawy w Bibliotece Raczyńskich: Poznań 5-30 maja 2015, Poznań-Gniezno 2015, s. 14-19.

${ }^{5}$ K. Rulka, Superekslibrisy w zbiorach Biblioteki Seminarium Duchownego we Włoctawku, „Studia Włocławskie”, 6 (2003) s. 528-530, 540-541, 547-548, 550-551.

${ }^{6}$ S. Rybandt, Superekslibrisy prymasa Stanisława Karnkowskiego w Bibliotece Uniwersyteckiej $w$ Warszawie, Z badań nad M. Sipayłto, Polskie superexlibrisy XVI-XVIII wieku w zbiorach Biblioteki Uniwersyteckiej $w$ Warszawie, Warszawa 1988, według indeksu: Jakub Uchański, Stanisław Karnkowski, Jan Wężyk, Władysław Aleksander Łubieński. polskimi księgozbiorami historycznymi, „Pogranicza”, 11 (1991) s. 5-26.

${ }^{7}$ M. Sipayłło, Polskie superexlibrisy XVI-XVIII wieku w zbiorach Biblioteki Uniwersyteckiej $w$ Warszawie, Warszawa 1988, wg indeksu: Jakub Uchański, Stanisław Karnkowski, Jan Wężyk, Władysław Aleksander Łubieński. 
go $^{8}$ oraz wspomnianego Arkadiusza Wagnera ${ }^{9}$ przeglądy tych form znaku własnościowego obejmujących również przykłady superekslibrisów stosowanych do oznaczania woluminów z księgozbiorów prymasów Polski, sugerują rozwinięte ambicje bibliofilskie gnieźnieńskich hierarchów w panoramie polskiego kolekcjonerstwa książki okresu wczesnonowożytnego.

Próba określenia ilości superekslibrisów prymasów Polski w Archiwum Archidiecezjalnym w Gnieźnie, możliwa za sprawą kwerendy prowadzonej w ramach projektu grantowego kierowanego przez dr. Piotra Pokorę ${ }^{10}$, uzupełniona o woluminy opisane w katalogu polskich druków XVI w. ks. Leona Formanowicza $^{11}$, pozwoliła na wskazanie grupy 21 typów i odmian ${ }^{12}$ superekslibrisów stosowanych przez dziewięciu arcybiskupów gnieźnieńskich (Maciej Drzewicki, Jan Latalski, Jakub Uchański, Stanisław Karnkowski, Bernard Maciejowski, Wojciech Baranowski, Jan Wężyk, Maciej Łubieński, Kazimierz Florian Czartoryski) w latach 1520/1531-1654/1673.

Zaprezentowane w formie katalogu typy i odmiany superekslibrisów uszeregowane zostały egzemplarzami zgrupowanymi osobowo w kolejności sprawowania godności prymasowskiej w Gnieźnie. W przypadku trzech hierarchów (Stanisław Karnkowski, Bernard Maciejowski, Wojciech Baranowski), liczba analizowanych jednostek katalogowych wynosi więcej niż jeden. Dla znaków własnościowych Maciejowskiego oraz Baranowskiego przyjęto za zasadne uznanie ich superekslibrisów właściwych, jako najliczniej występujących, za znaki prymarne, otwierające każdorazowo przegląd. Dla następnych wprowadzono zasadę kolejności chronologicznej. Przy dwóch typach superekslibrisów Baranowskiego, z powodu mniej precyzyjnej możliwości określenia daty ich wykonania, zdecydowano się przesunąć je na koniec zestawu introligatorskich znaków własnościowych tego hierarchy. Wobec obfitszej tradycji badawczej księgozbioru abpa Karnkowskiego oraz wprowadzeniu już pewnej numeracji kolejnych typów znaków własnościowych duchownego, uznano za właściwe zachować w poniższym katalogu porządek chronologiczny dla jego superekslibrisów.

Schemat opisu otwiera imię i nazwisko prymasa wraz z jego latami życia oraz herbem. W tym samym wierszu w prawym narożniku zamieszczono możliwy czas

${ }^{8}$ Z. Skiełczyński, Superekslibrisy z Biblioteki Kapitulnej w Lowiczu, Łowicz 1993, s. 4-5, 7, 16; tenże, Superexlibrisy Jana Wężyka arcybiskupa gnieźnieńskiego w Bibliotece Kapituły Łowickiej, „Wiadomości Archidiecezjalne Warszawskie”, 6-7 (1977) s. 174-178.

${ }^{9}$ A. Wagner, Superekslibris, według indeksu: Maciej Drzewicki, Andrzej Krzycki, Jan Latalski, Jakub Uchański, Stanisław Karnkowski, Wojciech Baranowski, Jan Wężyk, Maciej Łubieński.

${ }^{10}$ Projekt Inwentaryzacja zasobu Biblioteki Katedralnej w Gnieźnie finansowany jest z Narodowego Programu Rozwoju Humanistyki MNiSW (nr 11H 120179 81).

${ }^{11}$ Katalog Druków Polskich XVI-go wieku Bibljoteki Kapitulnej w Gnieźnie, oprac. L. Formanowicz, Poznań 1930, nr: 94, 190, 324, 349, 372, 417.

${ }^{12}$ Oparłem się o nomenklaturę stosowaną w badaniach numizmatycznych (np. R. Kiersnowski, Wstęp do numizmatyki polskiej wieków średnich, Warszawa 1964, s. 59-60) i sfragistycznych (zob. Z. Piech, Uwagi o typologii i nazewnictwie pieczęci w polskich i zagranicznych badaniach sfragistycznych, w: Dawne pieczęcie. Typologia-metody badań-interpretacje, red. Z. Piech, Warszawa 2015, s. 37-39). 
wykonania superekslibrisu na danej oprawie (w przypadku jednego egzemplarza), bądź większej ilości woluminów (w przypadku liczniejszej grupy) znajdujących się w Gnieźnie. Noty katalogowe uzupełniają również najniezbędniejsze informacje biograficzne o hierarchach, opisy opraw oraz próba ich atrybucji warsztatowej, informacje o innych znakach własnościowych w obrębie danego woluminu, literatura przedmiotu oraz uwagi.

Syn Jakuba kasztelana żarnowskiego i Katarzyny Libiszowskiej, od 1482 r. studia na uniwersytecie krakowskim, podkanclerzy koronny 1501, biskup przemyski 1503, kanclerz wielki koronny 1511, biskup włocławski 1513, arcybiskup gnieźnieński 1531.

Typ II

AAG, sygn. BK 2478

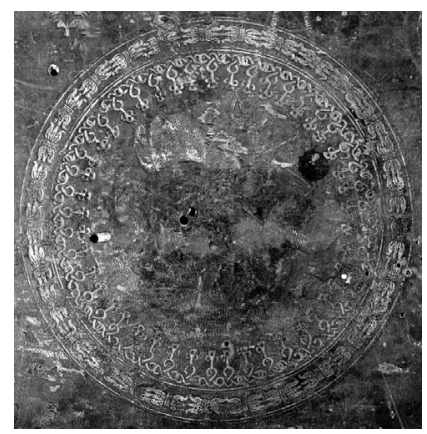

Pontificale secundum ritum Sacrosancte Romane Ecclesie cum multis additionibus opportunis ex apostolica bibliotheca sumptis (et) alias non impressis [...] opus sane laudabile atque divinum, Venetiis: Lucantonius Giunta, 1520; $2^{\circ}$.

Oprawa: deski, skóra brązowa, tłoczenia złoc., pozostałości po zapięciach mosiężno-skórzanych, wyciski tłoków w formie kwiatonów i anielskiej główki, górna okładzina - w górnej listwie napis: PONTIFICALE, w zwierciadle superekslibris malowany $(148 \times 143 \mathrm{~mm})$ Macieja Drzewickiego składający się z brązowego godła Ciołek na błękitnym tle w tarczy późnogotyckiej, powyżej po heraldycznej prawej infuła, po lewej pastorał krzywaśnią zwrócony w prawo, całość obwiedziona podwójnym wieńcem laurowym z przewiązkami i skierowanym do środka ornamentem trifoglio italiano.

Warsztat: Maciej z Przasnysza seu Mistrz Główek Anielskich (Kraków).

Proweniencje:

1. superekslibris: [Maciej Drzewicki].

2. ekslibris: drzeworyt z renesansową tarczą z godłem Ciołek, powyżej infuła i pastorał, po heraldycznej prawej od nich data 1516; całość w arkadzie; ponad ryciną napis: INSIGNE REVERENDISS(IMI) IN CHRISTO PA/TRIS. ET DOMINI DOMINI MATHIE / DREVICII EPISCOPI WLADISLA/VIENSIS.

3. Hic Liber applicatur Bibliothecae Adalbertum Wieczerkowicz [!] $S$ (anctae) $T$ (heologiae) D(octorem) Canonicum Gnesnensem (Wojciech Wieczorkiewicz (†1759) - doktor teologii, kanonik gnieźnieński). 
4. Ex Bibliotheca Reuerendissimi Capituli Metropolitani Gnesnensis (Gniezno kapituła katedralna).

Lit.: Pokora, „Pontificale Romanum”, s. 37-51;Pokora, Muraszko, Skarby, s. 15; Wagner, Prymas, s. $102-103$.

Uw.:

2) Jan Latalski (1463-1540) h. Prawdzic

$1531-1540$

Syn Jana kasztelana gnieźnieńskiego i Katarzyny z Oleśnicy, studia prawdopodobnie w Krakowie, nauka u grecysty Silvia de Mathio 1504, sekretarz królewski 1504, biskup poznański 1525, biskup krakowski 1536, arcybiskup gnieźnieński 1537.

Typ II

AAG, sygn. BK 1428

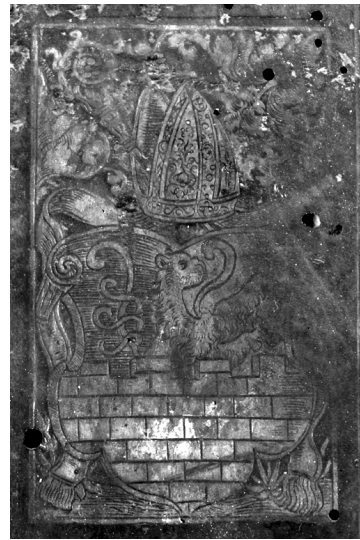

Opuscula Plutar[chi] Ch(a)eronei sedulo undequaq(ue) collecta, (et) dilige(n)ter recognita ac in unam facie $(\mathrm{m})$ bellatule coimpressa [...], Parisiis: officina Ascensiana (Josse Bade), 22 VI 1521; $2^{\circ}$.

Oprawa: deski, skóra brązowa, pozostałości zapięć mosiężno-skórzanych, tłoczenia złoc. i ślepe, tłoczenia 4 radełkami: postacie biblijne (ECCE AGNVS; [Zbawiciel]; [św. Paweł]; [św. Piotr]), sceny biblijne (PER ADAM MORS; PER CHRIST VITA; [wąż miedziany] z napisem między słupem NUM 21), sceny figuralne, wyciski w formie kwiatonów, rozetek i listków aldyńskich, górna okładzina - złocony superekslibris plakietowy Jana Latalskiego $(82 \times 50 \mathrm{~mm})$ składający się z godła Prawdzic w renesansowej tarczy, powyżej centralnie infuła skierowana en trois quarts w lewo, po heraldycznej prawej pastorał zwrócony w lewo o ozdobnej krzywaśni, po bokach pasy vittae, puste miejsca wypełniają ornamenty roślinne.

Warsztat poznański.

Proweniencje:

1. superekslibris: [Jan Latalski].

2. Ex Biblioth(eca) R(evere)n(dissi)mi Cap(itu)li Gnesnen(sis) (Gniezno - kapituła katedralna).

Lit.: Pokora, Muraszko, Skarby, s. 14. 
Uw.: filigran: skrzyżowane klucze, wskazuje na papiernię poznańską prowadzoną przez Tomasza Stempfera od 1531 r. (zob. Budka, Papiernie poznańskie, s. 142-145, rys. 2; Siniarska-Czaplicka, Filigrany, nr 845); identyfikacja miejsca wykonania oprawy - zob. Spuścizna Anny Lewickiej-Kamińskiej, sygn. 115-80; K. Piekarski rec. R. Kotula, s. 392; Wagner, Superekslibris, s. 252; inny typ - zob. Cubrzyńska-Leonarczyk, Polskie superekslibrisy, s. 34, tabl. 1.

3) Jakub Uchański (1502-1581) h. Radwan

$1577-1581$

Syn Pawła dziedzica na Uchaniach i Służewie oraz Weroniki z Jastrzębców, sekretarz wielki koronny 1548, biskup chełmski 1551, biskup włocławski 1561, arcybiskup gnieźnieński 1562.

Typ V

AAG, sygn. PL 232

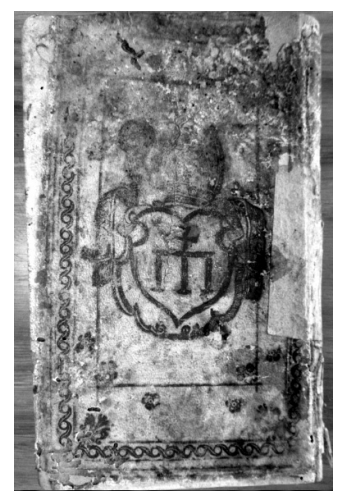

Brevis Augustissimi Summevenerandi Sacrosanctae Missae Sacrifici ex sanctis patrib(us) contra impium Francisci Stancari Mantuani scriptum, assertio. Iussu et Autoritate Reverendiss(imi) Domini Iacobi Uchanski Gnesnensis Archiepiscopi nunc primum edita [...], Coloniae Agrippinae: haeredes Arnoldi Birckmanni, $1577 ; 8^{\circ}$.

Oprawa: tektura, jasna skóra, tłoczenia złoc. i ślepe, radełko o motywie plecionki, wyciski tłoków w formie lilii, rozetek i listków, górna okładzina - plakieta prostokątna z chrystogramem, dolna okładzina - superekslibris introligatorski Jakuba Uchańskiego (całość $75 \times 62 \mathrm{~mm}$ ) składający się z osobnego wycisku renesansowej tarczy $(41 \times 36 \mathrm{~mm}) \mathrm{z}$ godłem Radwan oraz wycisku tworzącego ozdobny rollwerkowy kartusz uzupełniony o położoną centralnie ponad nim infułę, po prawej stronie mitry pastorał krzywaśnią skierowany w prawo, po bokach fanones.

Warsztat nieznany.

Proweniencje:

1. superekslibris: [Jakub Uchański].

2. Mon(asterii) Mogil(nensis) 1683 (benedyktyni - Mogilno).

3. Ex Bibliotheca Monasterij Mogilnensis Congrega(ti)onu(m) Benedictino=Polonae (benedyktyni - Mogilno).

Lit.: Katalog Druków Polskich XVI-go wieku Bibljoteki Kapitulnej w Gnieźnie, nr 417.

Uw.: wolumin poddany dawniej restauracji (wymieniono wyklejki, karty ochronne i podklejono niektóre karty); inne typy - zob. Rulka, Superekslibrisy, s. 528; Sipayłł, Polskie Superexlibrisy, s. 46-51, tabl. 7-9; Skiełczyński, Superekslibrisy, [s. 16]; Strelnik, Bibliofile, s. 72 (na podstawie 
opisu nie sposób wskazać, czy opisywane superekslibrisy odpowiadając któremuś z typów); Wagner, Superekslibris, s. 276-277, il. 112.

4) Stanisław Karnkowski (1520-1603) h. Junosza

$1558-1563$

Syn Tadeusza vel Dadźboga i Katarzyny z Olszewskich, studia: Uniwersytet Krakowski 1539, od 1545 prawdopodobnie w Perugii, Padwie i Wittenberdze, doktor obojga praw, referendarz koronny 1558, sekretarz wielki koronny 1563 , biskup włocławski 1567, arcybiskup gnieźnieński 1581.

Typ VIII

AAG, sygn. BKS 3294

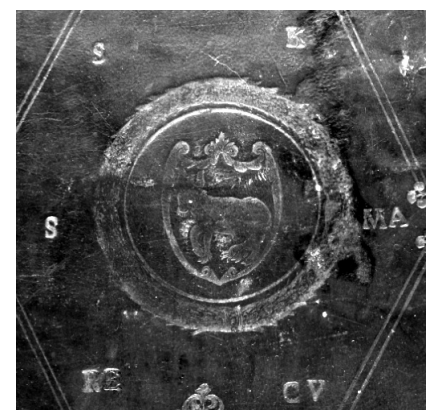

[Digestorum seu Pandectarum libri quinquaginta ex florentinis Pandectis repraesentati, [cz. 2], Florentiae: Laurentius Torrentinus, 1553]; $2^{\circ}$.

Oprawa: tektura, skóra bordowa, tłoczenia złoc i ślepe, 1 radełko o motywie plecionki, wyciski arabeskowe tłoków w formie listków i kwiatonów, górna okładzina - superekslibris introligatorski Stanisława Karnkowskiego (całość: 119x114 mm) składający się z tarczy kartuszowej $(49 \times 38 \mathrm{~mm})$ z Ciołkiem w godle, zamkniętej w okrągłym wieńcu laurowym $(80 \times 82 \mathrm{~mm})$, wokół w trzech rzędach sygle: S(TANISLAUS) K(ARNKOWSKI) / S(ACRAE) - MA(IESTATIS) / RE(FERENDARIUS) - $C V$ (RIAE).

Warsztat krakowski.

Proweniencje:

1. superekslibris: [Stanisław Karnkowski].

2. pieczęć: herb Junosza na kartuszu, powyżej infuła, napis w otoku: $S T A$ $N I S($ LAUS) $\bullet K A R N K O W S K I \bullet A R C H I E P(I S C O P U S) \bullet G N E Z N E N($ SIS).

3. Inscriptus catalogo libror(um) Seminarij Ecclesiae Metrop(olitanae) Gnesn(ensis) (Gniezno - Seminarium Duchowne).

Lit.: M. Bartoszak, Pozostałości, s. 47-48, il. 1; Pokora, Muraszko, Skarby, s. 17.

Uw.: filigran: herb Jastrzębiec z koroną, wskazuje na papiernię w Grembienicach (zob. Budka, Znaki wodne, nr 125, 126); inne typy - zob. Moskal, Książki, s. 196-198; Rulka, Superekslibrisy, s. 529; Rybandt, Księgozbiór, s. 123-124; tenże, Superekslibrisy, s. 5-26; Sipayłło, Polskie, s. 100-109, tabl. 34-38; Wagner, Superekslibris, wg indeksu. 
5) Stanisław Karnkowski (1520-1603) h. Junosza

$1586-1603$

Typ IX

AAG, sygn. BK 6346

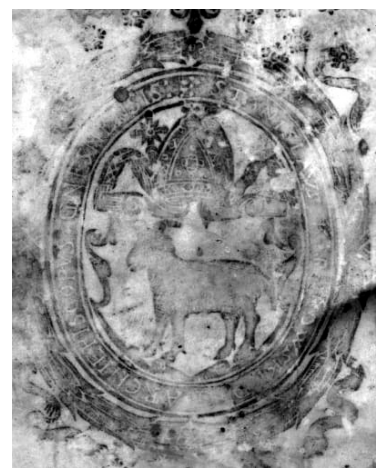

Epistolarum Illustrissimi ac Reverendissimi D(omini) D(omini) Caroli Cardinalis Borromaei nomine scriptarum. Libri II, Parisiis: Thomas Perier, 1586; $8^{\circ}$.

Oprawa: pergamin, tłoczenia złoc. i ślepe, tkane wiązania, wyciski tłoków w formie kwiatonów, listków i owoców granatu, górna okładzina - superekslibris właściwy Stanisława Karnkowskiego $(64 \times 54 \mathrm{~mm})$ złożony z rollwerkowej tarczy z Junoszą w godle, nad którą centralnie infuła i pasy vittae oraz krzyż metropolitalny, całość zamknięta wieńcu laurowo-inskrypcyjny z wstęgami (STANISLAVS : KARNKOWSKI D(EI) G(RATIA) : ARCHIEPISCOPVS • GNESNENSIS :+), dolna okładzina - ślad po okrągłym wycisku (superekslibrisie?).

Warsztat nieznany.

Proweniencje:

1. superekslibris: [Stanisław Karnkowski].

2. Iacob(us) Lempicki Ab(bas) lub(inensis) (Jakub Łempicki (1553-1608) - opat lubiński).

3. Conuentus Lubinensis Ord(inis) S(ancti) Bene(dicti) (benedyktyni - Lubiń).

Lit.:M. Bartoszak, Pozostałości, s. 48 (tam błędnie uznałem ten egzemplarz za odmianę typu I (II), il. 2 .

Uw.: Wycisk powstał najpewniej wskutek przerytowania tłoka służącego wcześniej podczas sprawowania godności biskupa włocławskiego do odciskania superekslibrisu w typie I (II) (zob. Rulka, Superekslibrisy, s. 529; Rybandt, Superekslibrisy, s. 13-14; Sipayłło, Polskie Superexlibrisy, s. 100, tabl. 34; Skiełczyński, Superekslibrisy, s. 7) - różnica zachodzi w przypadku krzyża zastępującego teraz pastorał oraz w uaktualnionym napisie w otoku.

6) Stanisław Karnkowski (1520-1603) h. Junosza

1588-1603

Typ V (Va)

AAG, sygn. BK 845

Illustrium Controversiarum Aliarumquae Usu Frequentium Libri tres: Authore D(omino) Fernando Vasquio Menchacensi [...], Genevae: Franciscus Faber (et) Iacobus Stoer, 1595; $4^{\circ}$. 


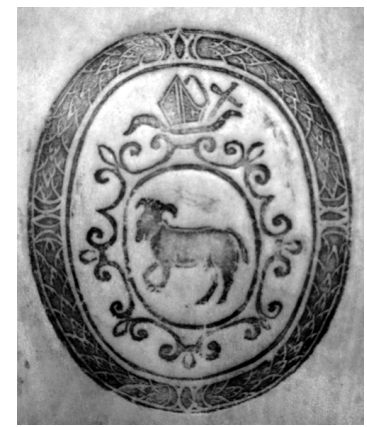

Oprawa: tektura, pergamin, wiązania rzemienne, grzbiet - rotundowy napis w typie hiszpańskim ze skróconym tytułem, tłoczenia złoc. i ślepe, 1 radełko: ornament sznurowy, wyciski tłoków w formie kwiatonu i główki maku, górna okładzina - plakieta z Chrystusem Salwatorem w wieńcu schweifwerkowo-inskrypcyjnym (IESVS CHRISTVS FILIVS DEI VIVI SALVATOR MVNDI ET DOMINVS DOMINANTI(VM), dolna okładzina - superekslibris właściwy Stanisława Karnkowskiego $(71 \times 58 \mathrm{~mm})$ składający się z owalnej tarczy z godłem Junosza położonej na kartuszu, zamknięte w stylizowanym laurowym wieńcu z przewiązkami kartusza $\mathrm{z}$ umieszczoną $\mathrm{u}$ góry infułą skierowaną en trois quarts w prawo oraz krzyżem metropolitalnym i pasami vittae.

Warsztat poznański.

\section{Proweniencje:}

1. superekslibris: [Stanisław Karnkowski].

2. Ex Libr(is) Admod(um) R(evere)ndi D(omini) Vincentii de Seue I(uris) $V$ (triusque) D(octoris) Lascen(sis) et Louicien(sis) Praepo(si)ti Archidiaconi. Gnesnen(sis) (Wincenty de Sevé $(\dagger 1611$ ) - doktor obojga praw, prepozyt łaski i łowicki, archidiakon gnieźnieński).

3. Ex Bibliotheca R(evere)nd(issi)mi Capituli Gnesnens(sis) (Gniezno - kapituła katedralna).

Lit.: Bartoszak, Pozostatości, s. 51-52; Moskal, Ksiązki, s. 197-198; Rulka, Superekslibrisy, s. 530; Rybandt, Superekslibrisy, s. 22, fot. 8; Sipayłł, Polskie Superexlibrisy, s. 108, tabl. 38; Wagner, Superekslibris, s. 227.

Uw.: filigran, herb Doliwa z inicjałami I R, wskazuje na papiernię w Murowanej Goślinie k. Poznania (zob. Budka, Znaki wodne, nr 258; Żurowski, Znaki wodne, nr 12); identycznej plakiety użyto na jednej z opraw kanonika gnieźnieńskiego Leonarda Walkonowskiego (zob. AAG, sygn. BK 2894; Franczak, Pozostałości, s. 35-36); superekslibris wyciśnięto również na górnej okładzinie woluminu BK 1478 (Commentaria Et Tractatus Hucusque Editi, atque nunc recens in unum collecti et in tres tomos distincti [...] D(omini) Martini ab Azpilcueta Navarri [...], Venetiis: Damianus Zenarius, 1588).

7) Stanisław Karnkowski (1520-1603) h. Junosza

Typ IIb (IVb)

AAG, sygn. PL 322 


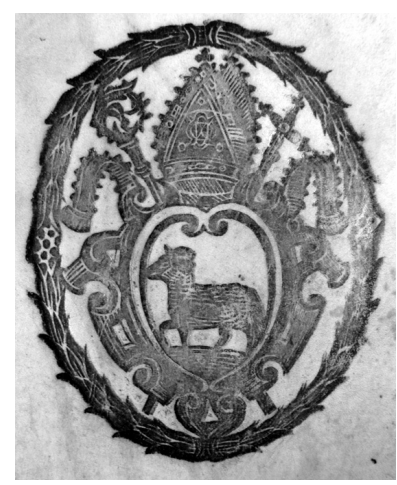

Messiasz Albo Kazania o Upadku Y Naprawie Rodzaiu Ludzkiego, Przez Przyście na świat Pana naszego Jezusa Christusa Syna Bożego; Przydane na końcu tegosz Auctora, O Dwoiakim Kosciele Chrześcijańskim., Poznań: [Barbara Wolrabowa i dzieci], $1597 ; 2^{\circ}$.

Oprawa: tektura, pergamin, otwory po wiązaniach, na grzbiecie skrócona wersja tytułu napisana rotundą w typie hiszpańskim, tłoczenia złoc. i ślepe, wyciski tłoków w formie kwiatonów, dolna okładzina - plakieta z wyobrażeniem Chrystusa (IESVS •CHRISTVS FILIVS • DEI • VIVI • SALVATOR $\bullet M V N D I \bullet R E X \bullet R E G V M \bullet E T \cdot D O M I N(V S) \bullet D O M I N A N T I V(\mathrm{M})$, górna okładzina - superekslibris Stanisława Karnkowskiego $(102 \times 70 \mathrm{~mm})$ składający się z godła Junosza w rollwerkowym kartuszu, nad nim centralnie umieszczona infuła, po lewej metropolitalny krzyż, po prawej zaś pastorał skierowany krzywaśnią do wewnątrz, po bokach fanones, całość okala owalny wieniec laurowy.

Warsztat poznański.

Proweniencje:

1. superekslibris: [Stanisław Karnkowski].

2. IE(g)o M(ości) X(iędzu) Biskupowi Ploczkiemu Autor D(ał) (Wojciech Baranowski (1548-1615) bp płocki 1591-1607, abp gnieźnieński 1608-1615).

3. Ex Cathalogo Libror(um) Biblioth(ecae) R(evere)n(dissi)mi Cap(itu)li Gnesnen(sis) (Gniezno - kapituła katedralna).

Lit.: Bartoszak, Pozostałości, s. 48, 50-51, il. 3; znacznie mniejszą (informacja dzięki uprzejmości autora) odmianę tego typu wzmiankuje Wagner, Superekslibris, s. 481; Katalog Druków Polskich XVI-go wieku Bibljoteki Kapitulnej w Gnieźnie, nr 190.

Uw.: superekslibris wizualnie nawiązuje do drzeworytu zastosowanego trzykrotnie w drukach poznańskiej oficyny Wolrabowej w latach 1586 i 1593 (zob. Chyczewska, Zasób, s. 367-368).

8) Bernard Maciejowski (1548-1608) h. Ciołek 1600-1605

Syn Bernarda kasztelana lubelskiego i Elżbiety z Kamienieckich, studia: Perugia 1583-1584, Rzym 1584, biskup łucki 1587, biskup krakowski 1600, kardynał 1605, arcybiskup gnieźnieński 1606. 
Typ I

AAG, sygn. BK 6089

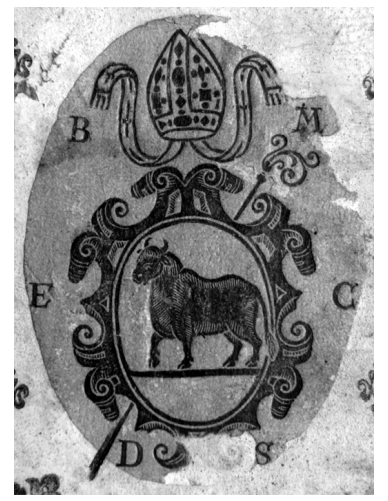

Benedicti Pererii [...] Quartvs Tomus Commentariorum In Librum Genesis. A capite vigesimo quinto usque ad quinquagesimum, (et) finem libri [...], Romae: Aloysius Zanettus, sumptibus Ioannis Antonii Franzini, (et) haeredum Hieronymi Franzini, 1599; $2^{\circ}$.

Oprawa: deski, jasna skóra, tłoczenia złoc. i ślepe, pozostałości po zapięciach mosiężno-skórzanych, 2 radełka: sceny biblijne (SATISFACTIO; [wąż miedziany]; PECCATVM; IUSTIFICACIO) i ewangeliści ze Zbawicielem (S. MATHE(VS); S. IOHAN(NES); S. LVCA(S); S. MARC(VS), wyciski floralne, górna okładzina - plakieta z Grupą Ukrzyżowania i napisem w otoku: $C H R I$ STVS FACTVS • EST • PRONOBIS • OBEDIENS • VSQVE • AD • MORTEM • MORTEM • AVTEM $\bullet$ CRVCIS: PHI(LIPPENSES): 2, tłoczenia liternicze w górnej i dolnej listwie: BENEDICTI / PERERII / TOMVS QVARTVS, dolna okładzina - złocony superekslibris właściwy Bernarda Maciejowskiego (całość: $84 \times 62 \mathrm{~mm})$ składający się z rollwerkowego kartusza $(58 \times 42$ $\mathrm{mm}$ ) przeciętego $\mathrm{z}$ lewa w skos pastorałem z krzywaśnią skierowaną w heraldyczną lewą, na kartuszu położona jest owalna tarcza $\mathrm{z}$ godłem Ciołek, nad kartuszem centralnie usytuowana infuła $\mathrm{z}$ fantazyjnie ułożonymi pasami vittae, całość okalają trzy rzędy sygli: $B$ (ERNARDUS) - $M$ (ACIEJOWSKI) / $E$ (PISCOPUS) - C(RACOVIENSIS) / $D$ (UX) - S(EVERIENSIS), superekslibris wyciśnięty na pomarańczowej podkładce papierowej.

Warsztat: Wilhelm (Kraków).

Proweniencje:

1. superekslibris: [Bernard Maciejowski].

Lit.: Poczet Prymasów, s. 61.

Uw.: filigran, herb Abdank w rollwerkowym kartuszu, wskazuje na papiernię w Mogile (zob. W. Budka, Znaki wodne, nr 58-63); identyfikacja warsztatu introligatorskiego na podstawie Spuścizna Anny Lewickiej-Kamińskiej, sygn. 93-80 (przerysy radełka ze scenami biblijnymi także w E. Laucevicius, XV-XVIII a. Knygu, nr 118, 314); superekslibris wyciśnięty ponadto na oprawach woluminów: BK 1568, BK 6475, BKS 2760, BKS 2903, BKS 3195 (identyczny repertuar zdobniczy z opisanym powyżej) oraz BKS 942 (druk z 1602 r., widoczne pęknięcia sugerujące częściowe zużycie klocka); być może ten sam znak wzmiankuje S. Poniatowski, Biblioteka, s. 121; prawdopodobnie identyczną infułę oraz krzywaśń pastorału zastosowano w superekslibrisie Michała Maliszewskiego (1595-1608) - zob. Sipayłł, Polskie Superexlibrisy, s. 138, tabl. 53. 
9) Bernard Maciejowski (1548-1608) h. Ciołek

$1601-1605$

Typ II

AAG, sygn. BK 4767

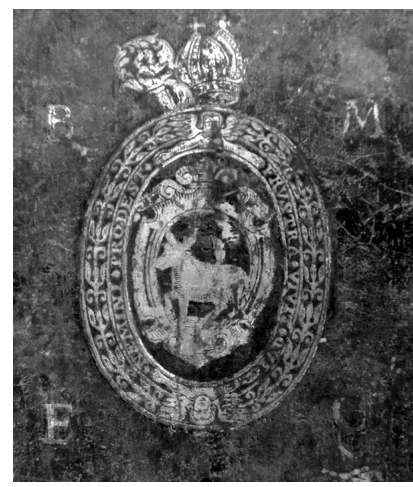

Flores Aurei Ex Paradiso Sacrae Scripturae Et Sanctorum Patrum, Super totius anni Dominicarum Evangelia collecti studio (et) industria F(ratris) Abraam Bzovii [...], Venetiis: Societas Minima, 1601; $4^{\circ}$.

Oprawa: tektura, ciemna skóra, tłoczenia złoc., ślady po wiązaniach, 1 radełko o motywie plecionki sznurowej, wyciski w formie kwiatonów i listków, 4 ćwierćmedaliony ze wyobrażeniami ewangelistów (kolejne od lewej u góry: S. IOANNES; S. MATHEVS; S. MARCVS; S. LVCA(S), górna okładzina - tłoczenia liternicze: FLORES AVREI EX PAR(ADISO) / SACRAE SCRIPTVRAE, górna i dolna okładzina - superekslibris introligatorski Bernarda Maciejowskiego (całość: $91 \times 74 \mathrm{~mm}$ ) składający się z owalnej tarczy z godłem Ciołek położonej na rollwerkowym kartuszu $(43 \times 32 \mathrm{~mm})$ zamkniętym w wieńcu $(71 \times 50 \mathrm{~mm})$ floralno-inskrypcyjnym $($ FRVSTRA • VIVIT $\bullet$ QVI - NEMINI $\bullet P R O D E S T)$, nad nim widoczna centralnie umieszczona infuła skierowana en trois quarts w prawo, po prawej krzywaśń pastorału zwrócona do wewnątrz, całość otaczają dwa rzędy sygli: $B$ (ERNARDUS) - M(ACIEJOWSKI) / $E$ (PISCOPUS) - C(RACOVIENSIS).

Warsztat krakowski.

Proweniencje:

1. superekslibris: [Bernard Maciejowski].

2. Collegio Poeniten(tiarium) Gnesnen(sium) $p($ er) $v(\mathrm{e}) n($ era $) b(\mathrm{i})$ lem Mathia(m) Lutouita(m) Plebanu(m) Uilcenen(sem) (Gniezno - kolegium penitencjarzy; Maciej Lutowita - penitencjarz gnieźnieński, pleban w Wilczynie).

Lit.: nienotowany.

Uw.: filigran: herb Lubicz w rollwerkowym kartuszu i klejnot złożony z pawich piór, wskazuje na papiernię w Grembienicach (zob. Budka, Znaki wodne, nr 143; Siniarska-Czaplicka, Filigrany, $\mathrm{nr} 562,565,566.568,569)$; identyczne narzędzia $\mathrm{z}$ wieńcem floralno-inskrypcyjnym oraz kartuszem wykorzystano przy wykonaniu superekslibrisu donacyjnego Abrahama Bzowskiego dla dominikanów krakowskich (zob. Sipayłło, Polskie Superexlibrisy, s. 158, tabl. 63) - w związku z obecnością w druku dedykacji Bzowskiego dla Bernarda Maciejowskiego przypisać należałoby temu znakowi własnościowemu charakter superekslibrisu dedykacyjnego. 


\section{0) Wojciech Baranowski (1548-1615) h. Jastrzębiec 1584 - po 1602}

Syn Mikołaja i Zofii z Gwiazdowskich, studia: przypuszczalnie Kraków i Padwa, kantor gnieźnieński 1581, sekretarz wielki koronny 1581, biskup przemyski 1584, podkanclerzy koronny 1585, biskup płocki 1591, biskup włocławski 1607, arcybiskup gnieźnieński 1608.

Typ I

AAG, sygn. BK 1543

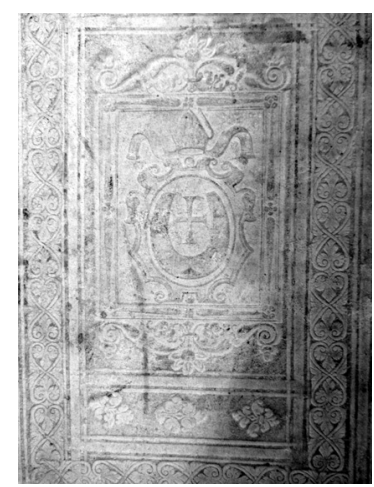

Bibliotheca Sancta A F(ratre) Sixto Senensi [...] Ex Praecipuis Catholicae Ecclesiae Authoribus Coll[e]cta, Et In Octo Libros Digesta [...] Denuo [...] recognita, et aucta, plurimisq(ue) in locis nunc a mendis expurgata, atq(ue) nova Chronographica tabula, secundum temporum collationem locupletata [...] Cum tribus locupletissima indicibus. Editio Tert[i], Coloniae: Maternus Cholinus, $1586 ; 2^{\circ}$.

Oprawa: tektura, biała skóra, tłoczenia ślepe, 3 radełka (1. głowy wojowników w wieńcach laurowych, między nimi ornament kandelabrowo-roślinny; 2. wyobrażenia muz: TAR(PSICHORA); POLI(HYMNIA); CALI (OPE); ELI(?); EVT(ERPE); 3. wić floralna), górna i dolna okładzina superekslibris właściwy Wojciecha Baranowskiego $(101 \times 55 \mathrm{~mm})$ składający się z umieszczonego na owalnej tarczy godła Jastrzębiec położonej na rollwerkowym kartuszu, ponad którym usytuowana jest centralnie infuła, po bokach pasy vittae, całość w prostokątnej ramce spiętej od góry i dołu wolutami wzbogaconymi ornamentami roślinnymi.

Warsztat: Kasper Rajman Starszy (Kraków).

Proweniencje:

1. superekslibris: [Wojciech Baranowski].

2. Ex Libris Alberti Wieczorkiewicz Can(oni)ci Gn(esnensis) $m$ (anu) p(ropria) (Wojciech Wieczorkiewicz $(† 1759)$ - doktor teologii, kanonik gnieźnieński)

3. Ex Bibliotheca R(evere)nd(iss)imi Capituli Metropol(itani) Gnesne(nsis) (Gniezno - kapituła katedralna).

Lit.: Katalog Druków Polskich XVI-go wieku Bibljoteki Kapitulnej w Gnieźnie, tabl. 1; Moskal, Ksiazkki, s. 199; Muraszko, Oprawy, il. 1, 3, 5 (w druku); Pokora, Muraszko, Skarby, s. 18-19; Wagner, Superekslibris, s. 386-387, il. 170a.

Uw.: filigran: herb Lubicz w rollwerkowym kartuszu, wskazuje na papiernię w Grembienicach (zob. Budka, Znaki wodne, nr 140, 142-146; Siniarska-Czaplicka, Filigrany, nr 535, 538, 539); identyfikacja oprawy - zob. Spuścizna Anny Lewickiej-Kamińskiej, sygn. 95-80; Chmiel, Oprawy, 
s. 17; superekslibris pojawia się w sumie na 72 oprawach (69 w AAG, 2 w Bibliotece Uniwersytetu Warszawskiego (sygn.: Sd. 612.35; Sd. 602.2338), 1 w Bibliotece Diecezjalnej w Sandomierzu (sygn. 14765), także powstałych w warsztacie gdańskiego introligatora posługującego się narzędziem ze syglami SS; tłok służący do wyciskania tego typu superekslibrisu wykorzystywany był przynajmniej do 1602 r. (rok druku dzieła z woluminu o sygn. BKS 3351).

\section{1) Wojciech Baranowski (1548-1615) h. Jastrzębiec 1584 - po 1591}

Typ Ia

AAG, sygn. BK 404

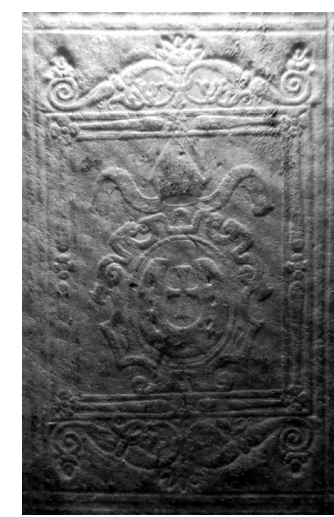

1. Hieronymi Osorii [...] Paraphrasis. In Isaiam: Libri V, Coloniae Agrippinae:

Officina Birckmannica (excudebat Godefridus Kempensis), 1584; $8^{\circ}$.

2. Hieronymi Osorii [...] De Vera Sapientia, Libri V [...], Coloniae Agrippinae: Officina Birckmannica, 1582; $8^{\circ}$.

Oprawa: tektura, biała skóra, tłocz. ślepe, 1 radełko: cztery popiersia wojowników w wieńcach laurowych, między nimi ornament roślinny, górna i dolna okładzina - superekslibris właściwy Wojciecha Baranowskiego $(73 \times 42 \mathrm{~mm})$ złożony z umieszczonej na rollwerkowym kartuszu owalnej tarczy z godłem Jastrzębiec, powyżej kartusza umieszczona en face infuła, po jej bokach fanones, całość zamknięta w prostokątnej ramce spiętej od góry i doły wolutami uzupełnionymi o ornamenty roślinne.

Warsztat: Kasper Rajman Starszy (Kraków).

Proweniencje:

1. superekslibris: [Wojciech Baranowski].

2. $R$ (evere)nd(issi)m[i] $C$ [apituli [...] Gnes]n(ensis?) (Gniezno - kapituła katedralna).

Lit.: Cubrzyńska-Leonarczyk, Polskie Superekslibrisy, s. 128, il. 45; M. Muraszko, Oprawy.

Uw.: identyfikacja warsztatu na podstawie radełka $\mathrm{z}$ wizerunkiem popiersi wojowników (zob. M. Muraszko, Oprawy; identyczne narzędzie w E. Laucevicius, XV-XVIII a. Knygu, nr 338, 353); superekslibris odnaleziono dotąd na 12 oprawach (11 w AAG (sygn.: BK 347, BK 375, BK 404, BK 443, BK 451, BK 516, BK 655, BK 3007, BK 3030, BK 4932, BK 4945), 1 w BUW (sygn. Sd. 608.3537) wykonanych także u gdańskiego introligatora SS; tłok służący do wy- 
ciskania tego typu superekslibrisu wykorzystywany był przynajmniej do $1591 \mathrm{r}$. (rok druku dzieła z woluminu BK 3007).

12) Wojciech Baranowski (1548-1615) h. Jastrzębiec

Typ II

AAG, sygn. PL 168

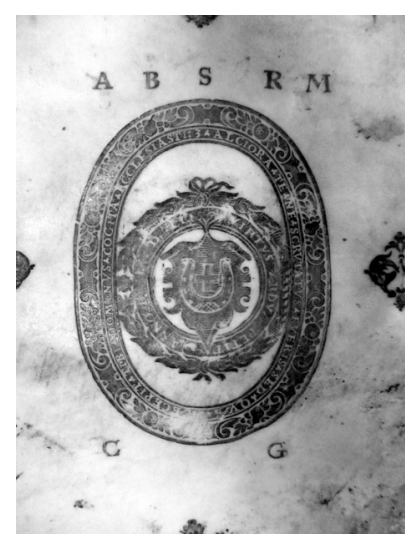

Liber De Modo Acquirendae Divinae Gratiae, quomodo cognoscantur eius adeptio, ac in ea permansio, per capita ac gradus quosdam digestus. Autore Hieronymo Sirino [...] Per Matthiam Clodinium [...] ex idiomate Italico in Latinam [...] versus: ac locis e scriptura sacra, unde haec deprompta sunt, abunde illustratus, Cracoviae: Officina Typographica Lazari, 1583; $4^{\circ}$.

Oprawa: pergamin, wiązania tkane, tłoczenia złoc., 1 radełko z ornamentem sznurowym, wyciski tłoków w formie kwiatonów, na grzbiecie zapisany rotundą skrót tytułu dzieła, górna okładzina - plakieta z wyobrażeniem Chrystusa Salwatora w wieńcu rollwerkowo-inskrypcyjnym $($ SALVATOR $\bullet M V N D I \bullet R E X \bullet R E G V M \bullet E T \cdot D O M I N V S \cdot D O M I N A N T I(V M) \bullet)$, tłoczenia liternicze (1584), dolna okładzina - superekslibris introligatorski Wojciecha Baranowskiego (całość: $80 \times 70 \mathrm{~mm})$ składający się z dwóch wieńców: 1 . wewnętrzny okrągły $(38 \times 40 \mathrm{~mm})$ laurowo-inskrypcyjny (VIRTVS ARDVA / PETIT ANNO D(OMINI) M. D. LI.) okalającego rollwerkowy kartusz z godłem Jastrzębiec; 2. zewnętrzny owalny (70x52 mm) girlandowo-rollwerkowy z otokiem inskrypcyjnym (ALCIORA - TE $\bullet$ NE $\bullet$ SCRVTATVS • FVERIS • SED • QVAE •PRAECEPIT • TIBI $・$ DOMINVS • COGITA • ECCLESIASTI(CVS): 3), na styku dwóch wieńców po prawej stronie wytłoczony ornament sznurowy, całość otoczona dwoma rzędami sygli $A$ (LBERTUS) $B$ (ARANOWSKI) $S$ (ECRETARIUS) $R$ (EGNI) $M$ (AIOR) $/ C$ (ANTOR) $G$ (NESNENSIS) nadpisanymi na niemal pozbawione złoceń sygle $S$ (TANISLAUS) $K$ (ONOPINSKI) / P(RAEPOSITUS) $B$ (LONENSIS).

Warsztat: Kasper Rajman Starszy (Kraków).

Proweniencje:

1. R(evere)ndo d(omi)no Stanislao Conopinskj Praeposito Blonen(si) Autor amico suo observ(andissi)mo in pignus perpetui amoris dedit (Stanisław Konopiński - proboszcz w Błoniach).

2. superekslibris: [Stanisław Konopiński].

3. superekslibris: [Wojciech Baranowski]. 
4. Ex Biblioth(eca): R(evere)n(dissi)mi Cap(itu)li Gnesn(ensis) (Gniezno - kapituła katedralna).

Lit.: Katalog Druków Polskich XVI-go wieku Bibljoteki Kapitulnej w Gnieźnie, nr 349; Muraszko, Matopolska, s. 241-246, il. 2.

Uw.: identyfikacja warsztatu introligatorskiego oprawy na podstawie tożsamości zastosowanej plakiety oraz narzędzi wykorzystanych do wyciśnięcia superekslibrisu (zob. Spuścizna Anny Lewickiej-Kamińskiej, sygn. 95-80); identyczny tłok z herbem Jastrzębiec otoczonym podwójnym wieńcem (w wersji z uszkodzonymi końcami wstęgami) posłużył także do wykonania superekslibrisu VI Jana Strzembosza (zob. Bylinowa, Renesansowy, s. 29-30, il. 13) oraz superekslibrisu III Wojciecha Baranowskiego; tłok ten (z całymi wstęgami) wykorzystany został wcześniej do wykonania opraw z superekslibrisami dla: anonima "I I" (Wagner, Superekslibris, s. 219, il. 58c), Jakuba Myszkowskiego (Korolev, Cenne, s. 186, il. 15) i Stanisława lub Zygmunta Myszkowskiego (Sipayłło, Polskie Superexlibrisy, s. 76, tabl. 22).

13) Wojciech Baranowski (1548-1615) h. Jastrzębiec

Typ III

AAG, sygn. PL 305

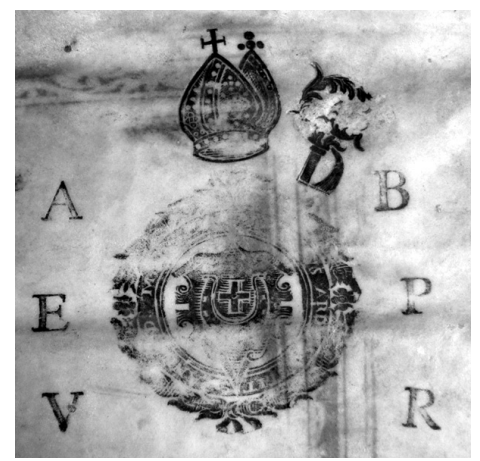

Stanislai Socolovii [...] Ad Wirtembergensium theologorum invectivam: quam actis et scripturis suis, cum Hieremia Patriarcha Constantinopolitano, de Augustana Confessione, per eos Graece et Latine editis, praefixerunt, Brevis responsio [...], Cracoviae: Officina Typographica Lazari, [post 13 VIII] 1584; $4^{\circ}$.

Oprawa: pergamin, wiązania rzemienne, tłoczenia złoc., górna okładzina - superekslibris introligatorski Wojciecha Baranowskiego (całość: $61 \times 65 \mathrm{~mm}$ ) składający się z rollwerkowej tarczy z godłem Jastrzębiec zamkniętej w okrągłym $(38 \times 40 \mathrm{~mm})$ wieńcu laurowo-inskrypcyjnym ([VIRTV]S $A R D$ [VA / PE]TIT AN[NO D(OMINI) $M$. [D. LI.]) z przewiązkami i wstążkami na osi wertykalnej oraz rozetkami na osi horyzontalnej, ponad wieńcem centralnie położona infuła zwrócona en trois quarts w prawo, po lewej pastorał skierowany krzywaśnią w lewo, wokół w trzech rzędach sygle $A$ (LBERTUS $)-B$ (ARANOWSKI) $/ E$ (PISCOPUS) $-P$ (REMISLIENSIS) $/ V$ (ICECANCELLARIUS) $-R($ EGNI)

Warsztat: Kasper Rajman Starszy (Kraków). 
Proweniencje:

1. superekslibris: [Wojciech Baranowski].

2. Ex Bibliotheca R(evere)n(dissi)mi Capituli Gnesnen(sis) (Gniezno - kapituła katedralna).

Lit.: Katalog Druków Polskich XVI-go wieku Bibljoteki Kapitulnej w Gnieźnie, nr 372.

Uw.: filigran: godło Lubicz w renesansowej tarczy, wskazuje na papiernię w Grembienicach (zob.

Budka, Znaki wodne, nr 140), identyfikacja warsztatu na podstawie tożsamości zastosowanego w superekslibrisie narzędzia z godłem Jastrzębiec (zob. Spuścizna Anny Lewickiej-Kamińskiej, sygn. 95-80), na powierzchni górnej okładziny odcisnął się fragment innej oprawy, identycznego narzędzia (z uszkodzonymi końcami wstęg) z herbem Jastrzębiec użyto do wykonania superekslibrisu VI Jana Strzembosza (zob. Bylinowa, Renesansowy, s. 29-30, il. 13) oraz superekslibrisu II Wojciecha Baranowskiego; tłok ten (z całymi wstęgami) wykorzystany został wcześniej do wykonania opraw z superekslibrisami dla: anonima I. I. (Wagner, Superekslibris, s. 219, il. 58c), Jakuba Myszkowskiego (Korolev, Cenne, s. 186, il. 15) i Stanisława lub Zygmunta Myszkowskiego (Sipayłło, Polskie Superexlibrisy, s. 76, tabl. 22).

14) Wojciech Baranowski (1548-1615) h. Jastrzębiec

$1585-1591$

Typ IV

AAG, sygn. PL 320

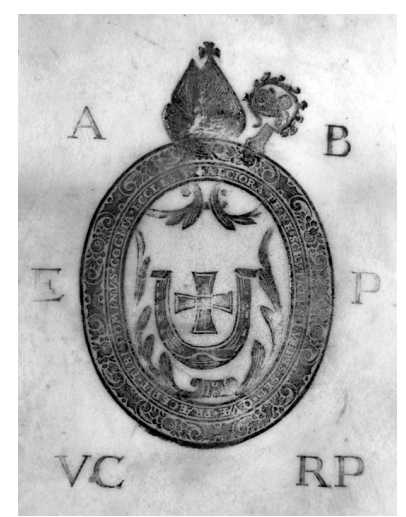

Pymander Mercurii Trismegisti Cum Commento Fratris Hannibalis Rosseli [...] Liber secundus de Spiritu S(ancti) (et) Angelis, Cracoviae: Officina Typographica Lazari, [post 23 I] 1585; $2^{\circ}$.

Oprawa: pergamin, wiązania tkane, tłoczenia złoc., wyciski tłoków w formie lilii, górna i dolna okładzina - superekslibris introligatorski Wojciecha Baranowskiego (całość: $80 \times 72 \mathrm{~mm}$ ) składający się z renesansowej tarczy kartuszowej z godłem Jastrzębiec zamkniętej w owalnym wieńcu $(62 \times 50 \mathrm{~mm})$ girlandowo-rollwerkowym $\mathrm{z}$ otokiem inskrypcyjnym (ALCIORA • TE $\bullet N E \bullet S C R V T A T V S \bullet F V E R I S \bullet S E D \bullet Q V A E \bullet P R A-$ ECEPIT •DOMINVS • COGITA • ECCLES (IASTICVS): 3), powyżej centralnie położona infuła, po lewej pastorał krzywaśnią skierowany do wewnątrz, wokół w trzech rzędach sygle: $A$ (LBERTUS) - $B$ (ARANOWSKI) / $E$ (PISCOPUS) - P(REMISLIENSIS) / $V$ (ICE) $C$ (ANCELLARIUS) $R$ (EGNI)P(OLONIAE).

Warsztat: Kasper Rajman Starszy (Kraków). 


\section{Proweniencje:}

1. superekslibris: [Wojciech Baranowski]

2. [...]Gnes[...] (wpis wydrapany) (Gniezno - kapituła katedralna ?)

Lit.: Katalog Druków Polskich XVI-go wieku Bibljoteki Kapitulnej w Gnieźnie, nr 324.

Uw.: filigran: herb Topór z koroną powyżej tarczy, wskazuje na papiernię w Tenczynku-Krzeszowicach (zob. W. Budka, Znaki wodne, nr 109); przyporządkowanie do warsztatu na podstawie tożsamości zastosowanych narzędzi z tarczą i godłem Jastrzębiec z wyciśniętymi na dolnej okładzinie prowadzonej pod nadzorem Baranowskiego księgi wpisów Metryki Koronnej z 1585 r. (AGAD, sygn. MK 131) wykonanej w warsztacie Kaspra Rajmana Starszego (identyfikacja na podstawie radełka jagiellońskiego - zob. Muraszko, Oprawy); identyczny wieniec zastosowany do wykonania superekslibrisu dedykacyjnego Jana Januszowskiego dla Piotra Dunin-Wolskiego na oprawie kryjącej piąty tom tego samego dzieła (zob. Obrębski, Oprawy, s. 139-140, fot. 15) oraz wykorzystany przy druku posiadanego przez Baranowskiego drugiego tomu dzieła papier $\mathrm{z}$ identycznym filigranem $\mathrm{z}$ tym zastosowanym przez introligatora, sugerują także dedykacyjny charakter tego superekslibrisu Wojciecha Baranowskiego będącym przypuszczalnie także darem drukarza Jana Januszowskiego.

15) Wojciech Baranowski (1548-1615) h. Jastrzębiec

Typ V

AAG, sygn. PL 224

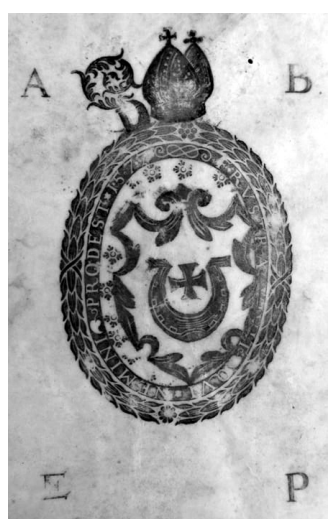

Iustus Ioseph sive In Iesu Christi Domini nostri mortem (et) passionem, Stanislai Socolovii [...] Meditationes. In quibus non magis Iudaica persidia, quam Ariana refutatur impietas, Cracoviae: Officina Lazari, [post 13 III] 1586; 4.

Oprawa: tektura, pergamin, wiązania tkane, tłoczenia złoc., wyciski tłoków o motywie floralnym, na grzbiecie rotundą skrót tytułu dzieła, górna i dolna okładzina - superekslibris introligatorski Wojciecha Baranowskiego (całość: $108 \times 63 \mathrm{~mm}$ ) składający się z renesansowej tarczy kartuszowej z godłem Jastrzębiec otoczonej owalnym wieńcem $(70 \times 54 \mathrm{~mm})$, z przewiązkami na osi horyzontalnej i rozetkami na wertykalnej, z otokiem inskrypcyjnym (FRVSTRA • VIVIT • QVI - NEMINI $\bullet$ PRODEST $\bullet 1 \cdot 5 \bullet 7 \bullet 7)$; w polu wieńca dodatkowo wyciski rozetek, nad wieńcem centralnie umieszczona infuła skierowana en trois quarts w prawo, po prawej pastorał zwrócony do wewnątrz, wokół dwa rzędy sygli $A$ (LBERTUS) - B(ARANOWSKI) / $E$ (PISCOPUS) $P$ (REMISLIENSIS).

Warsztat krakowski. 
Proweniencje:

1. superekslibris: [Wojciech Baranowski].

2. Ex Bibliotheca R(evere)nd(iss)imi Capituli Metropolitani Gnesnensis (Gniezno - kapituła katedralna).

Lit.: Katalog Druków Polskich XVI-go wieku Bibljoteki Kapitulnej w Gnieźnie, nr 368 II.

Uw.: filigran: widoczny fragment godła Jastrzębiec odmienny w tarczy, nad którą korona z trzema pałąkami, wskazuje na bliżej niezidentyfikowaną papiernię małopolską (najbardziej zbliżony do W. Budka, Znaki wodne, nr 195); identyczną tarczę z godłem Jastrzębiec zastosowano w superekslibrisie IIIa i IIIb Jana Strzembosza (Bylinowa, Renesansowy, s. 27-28, il. 9-10) oraz na dolnej okładzinie prowadzonej pod nadzorem Baranowskiego księgi wpisów Metryki Koronnej z lat 1587-88 (AGAD, MK 134); tożsamy wieniec laurowo-inskrypcyjny wykorzystano do wykonania superekslibrisów „I S” herbu Łabędź oraz Hieronima Rozrażewskiego (zob. E. Laucevicius, XV-XVIII a. Knygu, nr 362, 463), superekslibrisu IV Macieja Becha (Kawecka-Gryczowa, Nieznany, s. 122) oraz superekslibrisu anonima „I Z” herbu Ogończyk (Wagner, Superekslibris, il. 232b).

\section{6) Wojciech Baranowski (1548-1615) h. Jastrzębiec}

Typ VI

AAG, sygn. BK 5156

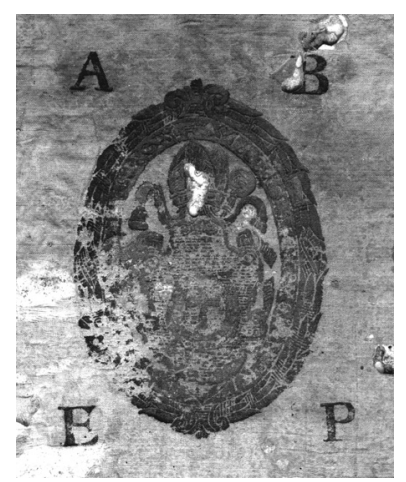

Christologiae seu Sermonum Pars Prior. In festis suae Divinissimae Infantiae sacratis, continens Sermones seu Orationes XX [...] Autore D(omino) Hieronymo Povodovio [...], Cracoviae: Andreas Petricovius, 1602; $4^{\circ}$.

Oprawa: tektura, jedwab, złocone i puncowane obcięcia bloku, tłoczenia złoc., 1 radełko $\mathrm{z}$ ornamentem sznurowym, wyciski tłoków w formie kwiatonu, dolna okładzina owalna plakieta z wyobrażeniem Chrystusa z napisem w otoku (IN • SOLE • POSVIT - TABERNACVLVM[・SV]VM • [...] • 18 (Ps 18,6), górna okładzina - superekslibris Wojciecha Baranowskiego (całość: $85 \times 65 \mathrm{~mm}$ ) składający się z godła Jastrzębiec umieszczonego na szrafowanym polu rollwerkowej tarczy kartuszowej $(35 \times 30$ $\mathrm{mm}$ ), powyżej centralnie umieszczona infuła, spod której wychodzą fanony, po lewej pastorał skierowany krzywaśnią do wewnątrz, całość otoczona owalnym wieńcem laurowym z otokiem inskrypcyjnym $(78 \times 56 \mathrm{~mm})(S T A N I S L A[\mathrm{US}]$ GOMO[LI]NSKI - D(EI):[G(RATIA) EPISCOPUS CHEL]MIENSIS - napis częściowo zaślepiony tło- 
czeniem radełka z ornamentem sznurowym), wokół w dwóch rzędach sygle $A$ (LBERTUS) - B(ARANOWSKI) / $E$ (PISCOPUS) $-P($ LOCENSIS).

Warsztat: Kasper Rajman Starszy (?).

\section{Proweniencje:}

1. superekslibris: [Wojciech Baranowski].

2. Ex libris Congr(egationis) Miss(ionis) Dom(us) Gnesn(ensis) (misjonarze Gniezno).

Lit.: M. Muraszko, Oprawy (w druku).

Uw.: filigran: herb Lubicz, wskazuje na papiernię w Grembienicach (zob. J. Siniarska-Czaplicka, Filigrany, nr 559-569); identyczne narzędzie $\mathrm{z}$ wieńcem oraz insygniami biskupimi posłużyło do wykonania superekslibrisu biskupa włocławskiego Pawła Wołuckiego z ok. 1600 r. (zob. PTPN, sygn. 102294. III - http://www.ptpn.poznan.pl/oprawy/ wyszukaj.php [dostęp: 29.06.2017]) w którym część inskrypcyjna również została zaślepiona tłoczeniem plecionkowym, oraz do wyciśnięcia po 1616 r., zredukowanego już o napis $\mathrm{w}$ otoku, superekslibrisu biskupa wileńskiego Eustachego Wołłowicza (Laucevicius, XV-XVIII a. Knygu, s. 93, nr 460) - zob. A. Wagner, Superekslibris, s. 479. W związ$\mathrm{ku} \mathrm{z}$ zastosowaniem $\mathrm{w}$ superekslibrisach Wołuckiego i Baranowskiego osobnego narzędzia z wieńcem i insygniami biskupimi oraz osobnych do wyciśnięcia tarczy kartuszowych zgodłamiherbowymi,którewobydwuprzypadkachniepokrywajązupełniewidocznejpodspodem pierwotnej części kartuszowej, wydaje się, że przyjąć można hipotezę o stosowaniu przez Stanisława Gomolińskiego tego tłoka do wyciskania superekslibrisów na oprawach własnych ksiąg w okresie piastowania przez niego godności biskupa chełmskiego, po jego przejściu w 1600 r. na biskupstwo łuckie, zdezaktualizowany klocek każdorazowo zaślepiany $\mathrm{w}$ części inskrypcyjnej uzupełniany był o tarczę $\mathrm{z}$ odpowiednim godłem, służąc jako komponent superekslibrisów introligatorskich innych hierarchów; tożsamym narzędziem $\mathrm{z}$ herbem Jastrzębiec zastosowanym do wykonania superekslibrisu VI Wojciecha Baranowskiego posłużył się Kasper Rajman Starszy (†1600/1603 r.) przy superekslibrisie dominikanina krakowskiego Grzegorza Cuneciusa wyciśniętym w $1580 \mathrm{r}$. (Pokora, Muraszko, Skarby, s. 20; Płaszczyńska-Herman, Ślady, s. 176, il. 5).

\section{7) Wojciech Baranowski (1548-1615) h. Jastrzębiec}

ok. 1584 (?)

Typ VII

AAG, sygn. PL 253

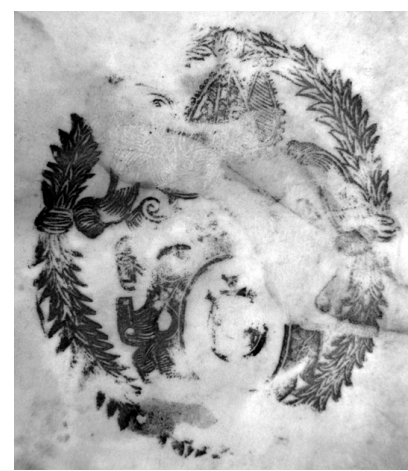


De Christi In Terris Ecclesia. Quaenam Et Penes Quos Existat. Libri Tres [...] contra falsas Antonij Sadeelis criminationes [...] Auctore Laurentio Arturo Faunteo [...], Posnaniae: Ioannes Wolrab, 1584; $4^{\circ}$.

Oprawa: tektura, pergamin, wiązania tkane, tłoczenia złocone, strychulec, wyciski w formie kwiatonu, dolna okładzina - plakieta z chrystogramem w wieńcu inskrypcyjnym (NON $\bullet E S T \bullet A L I V D$ - NOMEN • SVB • CAELO • DATVM • HOMINIBVS •IN • QVO • OPORTAT • SALVOS • FIERI $\bullet$ ), górna okładzina - superekslibris introligatorski Wojciecha Baranowskiego składający się z godła Jastrzębiec umieszczonego w owalnej tarczy położonej na rollwerkowym kartuszu, ponad którym widoczna jest centralnie usytuowana infuła skierowana en trois quarts w prawo, z prawej pastorał (?), po bokach pasy vittae, całość otoczona wieńcem laurowym z przewiązkami na osiach.

Warsztat pomorski (?).

Proweniencje:

1. superekslibris: [Wojciech Baranowski].

2. Ex Bibliotheca R(everen)d(i)s(si)mi Capituli Metropol(itani) Gnesnen(sis) (Gniezno - kapituła katedralna).

Lit.: Katalog Druków Polskich XVI-go wieku Bibljoteki Kapitulnej w Gnieźnie, nr 94.

Uw.: filigran, ryba w okręgu, zbliżona wizualnie do stosowanych w Prusach Książęcych (zob. Piccard watermarkcollection,nr44330 (https://www.piccard-online.de/detailansicht.php? klas$\mathrm{si}=037.001 .002 .001$ \&ordnr=44330\&sprache=en[dostęp:24.06.2017]), 44328

(https://www.piccard-online.de/detailansicht.php?klassi=037.001.002.001\&ordn$\mathrm{r}=44328 \&$ sprache $=$ en [dostęp:24.06.2017]), superekslibris częściowo zatarty.

18) Wojciech Baranowski (1548-1615) h. Jastrzębiec

$1584-1591(?)$

Typ VIII

AAG, sygn. BK 1038

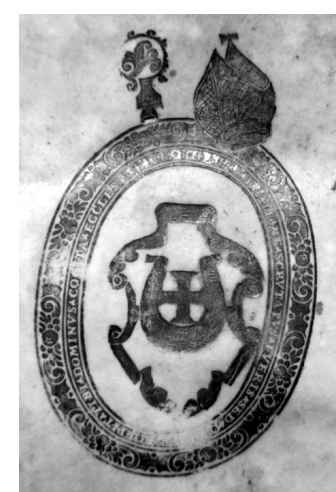

Flamini Nobilii [...] De Hominis Felicitate Libri tres. Ad Pium Quartum Pontificem Maximum. De Vera, (et) falsa Voluptate Libri duo. De Honore Liber unus. Ad Franciscum Medicem Florentinorum, Et Senensium Principem, Lucae: Vincentius Busdracus, 1563 (Var. A); $4^{\circ}$. 
Oprawa: pergamin, wiązania rzemienne, tłoczenia złocone, górna okładzina - superekslibris Wojciecha Baranowskiego (całość: $87 \times 53 \mathrm{~mm}$ ) składający się z renesansowej tarczy z godłem Jastrzębiec zamkniętej w podwójnym owalnym wieńcu $(71 \times 53 \mathrm{~mm})$ girlandowo-rollwerkowym i inskrypcyjnym $(A L C I O R A \bullet T E \bullet N E \bullet S C R V T A T V S \bullet F V E R I S \bullet S E D \bullet Q[V A E \bullet P] R A E C E P I T$ - TIBI • DOMINVS • COGITA • ECCESIASTICE. 3:), powyżej po lewej infuła, po prawej pastorał skierowany krzywaśnią na zewnątrz.

Warsztat krakowski.

Proweniencje:

1. superekslibris: [Wojciech Baranowski].

2. Ex Bibliotheca R(evere)nd(issi)mi Capituli Gnesnen(sis) (Gniezno - kapituła katedralna).

Lit.: Muraszko, Oprawy.

Uw.: filigran: godło Jastrzębiec (?), wskazuje na papiernię w Grembienicach (zob. Budka, Znaki, nr 128, 129, 133, 136, 137, 138), jako scezury użyto fragmentu karty s. 479-480 dzieła Bartosza Paprockiego Herby Rycerztwa Polskiego: Na pięcioro Xiag rozdzielone wydane w 1584 r. w krakowskiej oficynie Marcina Garwolczyka.

19) Jan Wężyk (1575-1638) h. Wąż

$1621-1638$

Syn Hieronima i Doroty Zaleskiej, studia: Kraków 1591, Rzym 1597, doktor obojga praw i teologii, kanonik krakowski, prepozyt sandomierski 1609, opat komendatoryjny mogilski 1613, biskup przemyski 1620, biskup poznański 1624, arcybiskup gnieźnieński 1627.

Typ III

AAG, sygn. BK 3645

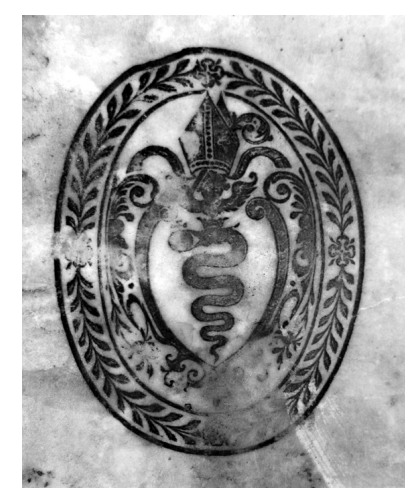

Tractatus De Distributionibus Quotitidianis, Tres In Partes Distributus. In Hac Tertia Editione Recognitus, Atque integris etiam quaestionibus, (et) decisionibus locupletus. Auctore Ioanne Petro Moneta [...], Romae: Angelus Ruffinellus (et) Angelus Mannus, $1621 ; 4^{\circ}$.

Oprawa: makulatura introligatorska (druk polski), pergamin, tłoczenia złoc. i ślepe, wiązania rzemienne, dolna okładzina - plakieta orientalizująca, górna okładzina - superekslibris właściwy Jana Wężyka $(61 \times 44 \mathrm{~mm})$ składający się z owalnego wieńca z gałązek oliwnych okalającego 
schweifwerkowy kartusz z godłem Wąż wzbogacony o dekoracje roślinne, zamknięty uskrzydloną główką, u góry centralnie położona infuła przecięta $\mathrm{z}$ lewa w skos pastorałem z krzywaśnią skierowaną do wewnątrz, po bokach pasy vittae.

Warsztat toruński (?).

Proweniencje:

1. superekslibris: [Jan Wężyk].

2. Ex Bibliotheca R(evere)n(diss)imi Capituli Metropolitani Gnesnensis (Gniezno - kapituła katedralna).

Lit.: Cubrzyńska- Leonarczyk, Polskie Superekslibrisy, s. 174, tabl. 68; Skiełczyński, Superexlibrisy, s. 177-178 (por. Poniatowski, Biblioteka, s. 121); Wagner, Superekslibris, s. 367, 379, il. 156.

Uw.: filigran: głowa jelenia z napisem w otoku: GORCA, wskazuje na papiernię pod Toruniem (zob. Piccard watermark collection, No. 83781, https://www.piccard- online.de/detailansicht. php? klassi $=015.001 .010 \&$ ordnr $=83781 \&$ sprache $=$ en [dostęp: 21.06.2017]); superekslibris identyczny z reprodukowanym przez M. Cubrzyńską-Leonarczyk, odbiega wielkością od wymiarów podanych przez Z. Skiełczyńskiego; kompozycja stylistyczna wydaje się nawiązywać do pieczęci herbowej Jana Wężyka jako opata mogilskiego z 1620 r. (zob. Starzyński, Herby, il. 41).

20) Maciej Lubieński (1572-1652) h. Pomian $1617-1621$

Syn Świętosława i Barbary Zapolskiej, studia: Kraków, Niemcy, Rzym, prepozyt bożogrobców w Miechowie 1617, biskup chełmski 1621, biskup poznański 1627, biskup włocławski 1631, arcybiskup gnieźnieński 1641.

Typ I

AAG, sygn. BK 3229

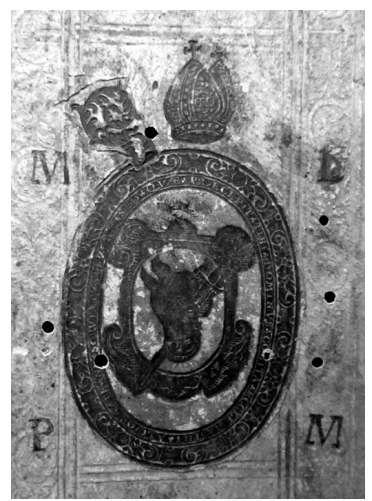

[Novissima Polyanthea, In Libros XX. Dispertita. Opus praeclarum, suavissimis floribus celebriorum sententiarum, cum Graecarum, tum Latinarum refertum [...] Dominico Nano Mirabellio, Bartholomaeo Amantio, Francisco Tortio, Francfurti: Haeredes Lazari Zetneri, 1617]; $2^{\circ}$.

Oprawa: deski, jasna skóra, pozostałości po zapięciach mosiężno-skórzanych, tłoczenia złoc. i ślepe, 2 radełka: 1. głowy wojowników w wieńcach, między nimi ornament roślinny z uskrzydlonymi główkami; 2. IVSTICIA; LVCRECIA; PRVDEN(CIA); 1604, górna okładzina - plakieta 
z wyobrażeniem Baranka Bożego w linearnym wieńcu inskrypcyjnym (AGNVS $D E I \bullet Q V I \bullet$ TOLLIS • PECCATA $\bullet M V N D I \bullet M I S E R E R E \bullet N O B I S \bullet:)$, wyciski floralne, w listwie powyżej zwierciadła tłoczenia liternicze: POLYANTHEA, dolna okładzina - superekslibris introligatorski Macieja Łubieńskiego (całość: $95 \times 70 \mathrm{~mm}$ ) składający się z godła Pomian w owalnej tarczy położonej na kartuszu $(40 \times 33 \mathrm{~mm})$ o półkolistym polu na nasadzie oraz czterech narożnikowych wolutach, otoczonym podwójnym wieńcem $(71 \times 53 \mathrm{~mm})$ złożonym z girlandy i rollwerku oraz otoku inskrypcyjnego $($ ALCIORA $\bullet$ TE $\bullet$ NE $\bullet$ SCRVTATVS $\bullet$ FVERIS $\bullet$ SED • QVAE $\bullet P R A E C E P I T \cdot T I B I \bullet D O M I N V S \bullet C O G I T A \bullet E C C L E S I A S T I(C U S): 3)$, powyżej infuła skierowana en trois quarts w prawo, po prawej pastorał zwrócony krzywaśnią do wewnątrz, po bokach w dwóch rzędach sygle: $M$ (ATTHIAS) - L(UBIENSKI) / P(RAEPOSITUS) - M(IECHOVIENSIS.

Warsztat krakowski.

Proweniencje:

1. superekslibris: [Maciej Łubieński]

2. [...] Dominici $[\ldots]$ cietkowskij $S[\ldots] M[\ldots]$

Lit.: Cubrzyńska-Leonarczyk, Polskie Superekslibrisy, s. 180, tabl. 71; Wagner, Superekslibris, s. 391-393.

Uw.: indentyfikacja warsztatowa oprawy na podstawie Wagner, Superekslibris, s. 391-393; litera L w superekslibrisie nadbita została na literze P; inne typy - Laucevicius, XV-XVIII a. Knygu, nr 451; Rulka, Superekslibrisy, s. 540; Wagner, Superekslibris, il. 181.

21) Kazimierz Florian Czartoryski (ok. 1614-1674) h. Pogoń 1654-1673

Syn Mikołaja Jerzego wojewody wołyńskiego i Izabeli z Książąt Koreckich, studia: Rzym, doktor teologii, biskup poznański 1650, biskup włocławski 1655, arcybiskup gnieźnieński 1673.

Typ I

AAG, sygn. BK 3243

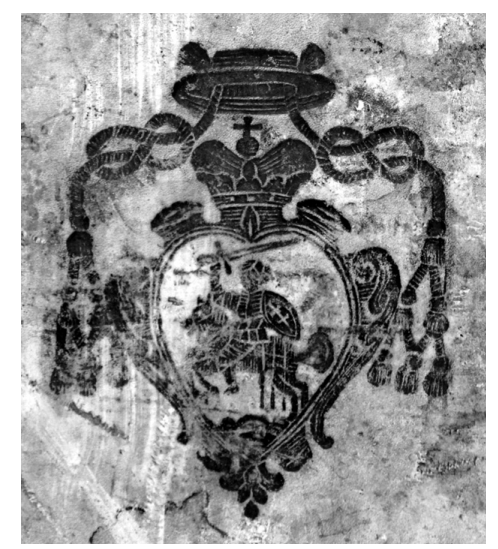

Sancti Aurelii Augustini Milleoquium Veritatis; Olim A Fr(atre) Bartholomaeo Ord(inis) S(ancti) Augustini Urbinate Episcopo Digestum; Nunc vero plurimis eiusdem Sancti Sententiis locupletatum; Opera Ioan (nis) Collierii Presbytero Theologi: In Quo Unici Illius Augustini Doctrina mille Titulis seu Locis communibus in ordinem Alphabeticum redactis, ita breviter et summatim comprenditur [...] 
Opus omnibus Literarum bonarum, (et) maxime sacrarum Studiosis cum primis utile (et) necessarium [...], Lutetiae Parisiorum: Sébastien Huré, 1649; $2^{\circ}$.

Oprawa:deski, jasna skóra, pozostałości po zapięciach mosiężno-skórzanych, tłoczenia na złoc. i ślepe, 2 radełka: 1. ornament palmetowo-arkadowy; 2. ornament floralny, wyciski tłoków w formie arabeski, dolna okładzina - romboidalna plakieta arabeskowa z kaboszonem, górna okładzina - złocony superekslibris właściwy Kazimierza Floriana Czartoryskiego $(70 \times 58 \mathrm{~mm})$ składający się z sercowatej tarczy z godłem Pogoń położonej na kartuszu z ornamentem barokowym, u góry mitra książęca, nad nią kapelusz biskupi z 6 chwostami po bokach.

Warsztat nieznany.

Proweniencje:

1. superekslibris: [Kazimierz Florian Czartoryski].

2. Residenciae Medirecensis Soc(ietatis) Jesu (jezuici - Międzyrzecz).

3. Conventus Kcynensis Ordinis Carmelitarum (karmelici trzewiczkowi - Kcynia).

4. ekslibris: $Z$ daru testam (entowego) $X$ (iędza) $A$ (ntoniego) Dyamenta (Antoni Dyament (1801-1885) - notariusz apostolski, penitencjarz katedralny gnieźnieński).

Lit.: Iwańska-Cieślik, Biblioteka, s. 96; Pokora, Muraszko, Skarby, s. 16; Rulka, Superekslibrisy, s. 540 .

Uw.:

\section{BIBLIOGRAFIA}

\section{Źródła}

Archiwum Archidiecezjalne w Gnieźnie

sygn. BK 347, BK 375, BK 404, BK 443, BK 451, BK 516, BK 655 BK 845, BK 1068 , BK 1428, BK 1478, BK 1543, BK 1568, BK 2478, BK 2894, BK 3007, BK 3030, BK 3229, BK 3243, BK 4767, BK 4932, BK 4945, BK 5156, BK 6089, BK 6346, BK 6475, BKS 942, BKS 2760, BKS 2903, BKS 3195, BKS 3294, PL 168, PL 224, PL 232, PL 253, PL 305, PL 320, PL 322.

Archiwum Główne Akt Dawnych

sygn. MK 131, MK 134.

Biblioteka Jagiellońska

Spuścizna Anny Lewickiej-Kamińskiej, sygn.: 93-80, 95-80, 115-80.

Biblioteka Uniwersytetu Warszawskiego

sygn. Sd. 602.2338, Sd. 608.3537, Sd. 612.35.

\section{Opracowania}

Bartoszak M., Pozostałości księgozbioru prymasa Stanisława Karnkowskiego w Archiwum Archidiecezjalnym w Gnieźnie, „Roczniki Biblioteczne”, 61 (2017) s. 35-65. 
Budka W., Papiernie poznańskie, w: W. Budka, Historia papiernictwa: antologia prac historyka papiernictwa Włodzimierza Budki, [Łódź]-Duszniki-Zdrój 2009, s. 142-148.

Budka W., Znaki wodne papierni w Rzeczypospolitej Polskiej XVI w., w: Papiernie w Polsce XVI w., wyd. W. Budka, Wrocław-Warszawa-Kraków-Gdańsk 1971, s. 6979.

Bylinowa E., Renesansowy księgozbiór rodziny Strzemboszów, w: Kolekcje Historyczne. Ksieggozbiory Szlacheckie XVI-XVIII wieku, red. E. Wyszyńska, Warszawa 2004, s. 17-105.

Chmiel A., Oprawy introligatora krakowskiego Kaspra Rajmana (Starszy) 1566-1600, „Przemysł i Rzemiosło”, 1 (1921) z. 1, s. 14-20.

Chyczewska A., Zasób drzeworytów ilustracyjnych i herbowych w XVI-wiecznych oficynach poznańskich, w: Z zagadnień teorii i praktyki bibliotekarskiej. Studia poświęcone pamięci Józefa Grycza, Wrocław-Warszawa-Kraków 1961, s. 354-382.

Cubrzyńska-Leonarczyk M., Polskie superekslibrisy XVI-XVIII wieku: centuria druga, Warszawa 2001.

Franczak R., Pozostałości księgozbioru kanonika gnieźnieńskiego Leonarda Walkonowskiego w zasobie Archiwum Archidiecezjalnego w Gnieźnie, „Archiwista Polski”, 3 (2014) s. 31-39.

Iwańska-Cieślik B., Biblioteka kapituły katedralnej we Włocławku, Bydgoszcz 2013.

Katalog Druków Polskich XVI-go wieku Bibljoteki Kapitulnej w Gnieźnie, oprac. L. Formanowicz, Poznań 1930.

Kawecka-Gryczowa A., Nieznany bibliofil polski XVI wieku Maciej Bech, „Roczniki Biblioteczne" 21 (1977) z. 1-2, s. 117-140.

Kiersnowski R., Wstęp do numizmatyki polskiej wieków średnich, Warszawa 1964.

Korolev S., Cenne i rzadkie polskie superekslibrisy heraldyczne ze zbiorów Biblioteki Narodowej $w$ St. Petersburgu, „Z badań nad książką i księgozbiorami historycznymi”, 3 (2009) s. 171-196.

Laucevicius E., XV-XVIII a. Knygu irisimai Lietuvos Bibliotekose, Mosklas-Vilnius 1976.

Moskal T., Ksiązki z superekslibrisami biskupów polskich okresu przedrozbiorowego $w$ Bibliotece Decezjalnej w Sandomierzu, w: Artem aliis tradere. Ksiega pamiatkowa ku czci Księdza Profesora Anzelma Weissa, red. W. Bielak, J. Marczewski, T. Moskal, Lublin 2011, s. 193-205.

Muraszko M., Matopolska oprawa „Liber de modo acquirendae divinae gratiae...” z księgozbioru arcybiskupa Wojciecha Baranowskiego, ,Acta Universitatis Wratislaviensis. Studia o Książce i Informacji”, 36 (2017) s. 241-246.

Muraszko M., Oprawy ksiag arcybiskupa gnieźnieńskiego Wojciecha Baranowskiego, w: O miejsce książki w historii sztuki - Państwo i Kościót. W rocznicę chrztu Polski, Kraków 2018 (w druku).

Obrębski A., Oprawy książek należacych do przechowywanej w zbiorach Biblioteki Jagiellońskiej Volsciany, „Biuletyn Biblioteki Jagiellońskiej”, 41 (1991) s. 133-145.

Piech Z., Uwagi o typologii i nazewnictwie pieczęci w polskich i zagranicznych badaniach sfragistycznych, w: Dawne pieczęcie. Typologia - metody badań-interpretacje, red. Z. Piech, Warszawa 2015, s. 15-46.

Piekarski K. rec. R. Kotula, Właściciele rękopisów i starodruków zbiorów wielkopolskich Z. Czarneckiego, mieszczacych się obecnie w „Baworovianum” we Lwowie, Lwów 1929, „Przegląd Bibljoteczny”, 3 (1929) z. 3, s. 388-415.

Płaszczyńska-Herman K., Ślady bibliofilskiej działalności braci kaznodziejów - superekslibrisy dominikańskie z biblioteki oo. dominikanów w Krakowie, w: Tegumentologia Polska Dzisiaj, red. A. Wagner, Toruń 2016, s. 167-189. 
Pokora P., ,,Pontificale Romanum” z 1520 roku z biblioteki prymasa Macieja Drzewickiego. O odnalezieniu jednego z zaginionych klejnotów Biblioteki Katedralnej w Gnieźnie, „Biblioteka”, 17 (2013) s. 37-51.

Pokora P., Muraszko M., Skarby drukarstwa i introligatorstwa ze zbiorów dawnej Biblioteki Katedralnej w Gnieźnie. Katalog wystawy w Bibliotece Raczyńskich: Poznań 5-30 maja 2015, Poznań-Gniezno 2015.

Poniatowski S., Biblioteka kapituly łowickiej (zarys dziejów) w: Z badań nad polskimi księgozbiorami historycznymi. Bibliologia dyscyplina integrujaca, Warszawa 1993, s. 119-125.

Rulka K., Superekslibrisy w zbiorach Biblioteki Seminarium Duchownego we Włocławku, „Studia Włocławskie”, 6 (2003) s. 527-557.

Rybandt S., Księgozbiór prymasa Stanisława Karnkowskiego. Źródło badań nad kultura umystowa dostojnika kościelnego XVI w., „Z badań nad polskimi księgozbiorami historycznymi", 13 (1992) s. 117-130.

Rybandt S., Superekslibrisy prymasa Stanisława Karnkowskiego w Bibliotece Uniwersyteckiej $w$ Warszawie, „Z badań nad polskimi księgozbiorami historycznymi”, 11 (1991) s. 5-26.

Siniarska-Czaplicka J., Filigrany papierni położonych na obszarze Rzeczypospolitej Polskiej od początku XVI do połowy XVIII wieku, Wrocław 1969.

Sipayłł M., Polskie Superexlibrisy XVI-XVIII wieku, Warszawa 1988.

Skiełczyński Z., Superekslibrisy z Biblioteki Kapitulnej w Łowiczu, Łowicz 1993.

Skiełczyński Z., Superexlibrisy Jana Wężyka arcybiskupa gnieźnieńskiego w Bibliotece Kapituły Łowickiej, „Wiadomości Archidiecezjalne Warszawskie”, 6-7 (1977) s. 174178.

Starzyński M., Herby średniowiecznych opatów mogilskich, Kraków 2005.

Strelnik I., Bibliofile XVI i XVII wieku i ich książki w Bibliotece im. Lopacińskiego, ,Rocznik Lubelski", 23/24 (1981/1982) s. 65-77.

Wagner A., Prymas Maciej Drzewicki jako bibliofil. W pięćsetlecie powstania powstania pierwszego polskiego ekslibrisu, Warszawa-Toruń-Poznań-Drzewica 2016.

Wagner A., Superekslibris polski: studium o kulturze bibliofilskiej i sztuce od średniowiecza do połowy XVII wieku, Toruń 2016.

Żurowski S., Znaki wodne papiernictwa wielkopolskiego XVI-XIX w., Zeszyty Naukowe Uniwersytetu im. Adama Mickiewicza w Poznaniu, „Biblioteka”, $5 / 57$ (1965) s. 255316.

\section{Netografia}

internetowa baza Piccard Watermark Collection: https://www.piccard-online.de/strukt ur. php? sprache=en (dostęp: 30.06.2018).

internetowa baza opraw zabytkowych XV-XVIII w. Poznańskiego Towarzystwa Przyjaciół Nauk: http://www.ptpn.poznan.pl/oprawy/oprawa7.php (dostęp: 30.06.2018). 


\title{
SUPEREKSLIBRISY PRYMASÓW POLSKI Z XVI- I XVII WIEKU ZNAJDUJĄCE SIĘ W ARCHIWUM ARCHIDIECEZJALNYM W GNIEŹNIE
}

\begin{abstract}
Streszczenie
Kwerenda przeprowadzona w trakcie projektu grantowego realizowanego pod kierownictwem dr. Piotra Pokory w Archiwum Archidiecezjalnym w Gnieźnie umożliwiła wskazanie grupy 21 typów i odmian superekslibrisów stosowanych przez 9 arcybiskupów gnieźnieńskich XVI i XVII w. Usystematyzowane osobowo znaki własnościowe, w pozytywny sposób świadczące o trosce o estetyczną okazałość woluminów hierarchów, dowodzą zarazem ich rozwiniętych ambicji bibliofilskich. W omawianym zbiorze uwidocznione zostały fluktuacje popularności tej formy znaku własnościowego. Trwający mniej więcej do połowy XVI w. etap implementacyjny objawił się jedynie sporadycznymi przykładami reprezentowanymi przez pojedyncze superekslibrisy Macieja Drzewickiego i Jana Latalskiego. Rozwój ilościowy dostrzegalny od drugiej połowie XVI w. uwidoczniony został w książkowych znakach Jakuba Uchańskiego, Stanisława Karnkowskiego, Bernarda Maciejowskiego, Wojciecha Baranowskiego, Jana Wężyka i Macieja Łubieńskiego dla których wachlarz typów i odmian superekslibrisów uległ już zdecydowanemu rozrostowi. Regres dostrzegalny wśród polskich miłośników książek w ciągu XVII w. skutkował mniej zasobną listą dalszych przykładów, które reprezentuje tutaj jedynie superekslibris Kazimierza Floriana Czartoryskiego. Opis pojedynczego egzemplarza uwzględnia tytuł, rok i miejsce wydania druku, opis oprawy wraz z próbą identyfikacji warsztatu introligatorskiego, jak też inne znaki proweniencyjne w obrębie woluminu, a także powiązaną z danym superekslibrisem literaturę przedmiotową.
\end{abstract}

Słowa kluczowe: Archiwum Archidiecezjalne w Gnieźnie; arcybiskupi gnieźnieńscy; superekslibris; starodruki; nauka o książce

\section{THE SUPROLIBROS OF THE PRIMATES OF POLAND OF THE 16TH AND 17TH CENTURIES HELD IN THE ARCHDIOCESAN ARCHIVE IN GNIEZNO}

\begin{abstract}
Summary
The research conducted as part of a grant project under the supervision of Dr Piotr Pokora in the Archdiocesan Archive in Gniezno resulted in presenting the group of 21 types of supralibros used by nine archbishops of Gniezno in the 16th and 17th century. The owner's marks separately arranged, reflecting hierarchs' care about aesthetic values of their volumes, reveal archbishops' great bibliophilic ambitions. The collection under investigation presents how the popularity of these types of owner's marks fluctuated. The
\end{abstract}


implementation stage, which lasted to the mid-16th century, is represented only by occasional examples of single supralibros of Maciej Drzewicki and Jan Latalski. The increase in number which is noticed in the second half of the 16th century is revealed in the owner's marks of Jakub Uchański, Stanisław Karnkowski, Bernard Maciejowski, Wojciech Baranowski, Jan Wężyk and Maciej Łubieński, for whom a range of types and varieties of supralibros expanded considerably. The decline among Polish book lovers in the 17 th century resulted in a scant list of further examples, represented here only by the supralibros of Kazimierz Florian Czartoryski. The description of a particular book includes the title, the year and place of its publishing, the description of the cover along with an attempt to identify the bookbinding workshop and other marks of provenance, as well as the literature related to the given supralibros.

Keywords: the Archdiocesan Archive in Gniezno; archbishops of Gniezno; supralibros; antique books; the study of the book 